\title{
Giant iridodialysis with wound dehiscence following penetrating keratoplasty: an ocular emergency
}

\author{
Jayanand S Urkude, Amar Pujari, Manthan Chaniyara, Rashmi Singh
}

Department of Ophthalmology, Dr Rajendra Prasad Centre for Ophthalmic Sciences, All India Institute of Medical Sciences, New Delhi, India

\section{Correspondence to} Dr Jayanand S Urkude drjay2910@gmail.com

Accepted 19 May 2017

\section{DESCRIPTION}

Wound dehiscence is a known complication of keratoplasty which can occur even many years following the surgery. Usually trivial trauma is the causative factor for wound dehiscence, but spontaneous dehiscence has also been reported in the literature. ${ }^{1}$

A 45-year-old man presented with sudden loss of vision in the left eye following a blunt trauma. History revealed penetrating keratoplasty in the left eye for perforated corneal ulcer 2 years ago. On examination, visual acuity was hand movement close to face in the left eye and right eye being within normal limits with $20 / 20$ visual acuity. Slit-lamp biomicroscopic examination showed broken monofilament nylon sutures leading to superior 6 clock hours (09:00 to 03:00 clock hours) of wound dehiscence, with corresponding 6 clock hours of giant iridodialysis prolapsing anteriorly (figure 1). The lens was completely extruded along with vitreous at the wound. Based on the relevant history and clinical findings, a diagnosis of giant iridodialysis secondary to wound dehiscence following blunt trauma was made. As the injury was more than 48 hours old, the prolapsed iris tissue was abscissed along with limited anterior vitrectomy followed by resuturing of the same graft to the host bed under general anaesthesia. First postoperative day showed a well-apposed graft-host junction (GHJ), with a well-formed anterior chamber (figure 2). At the end of 5 months, the patient is without any

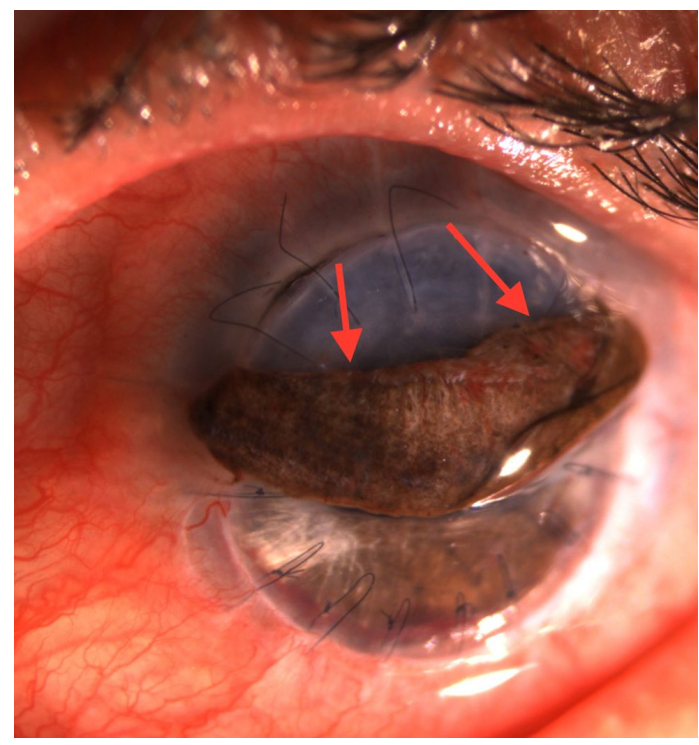

Figure 1 Superior 6 clock hours of giant iridodialysis extending from 09:00 to 03:00 clock hours with corresponding wound dehiscence.

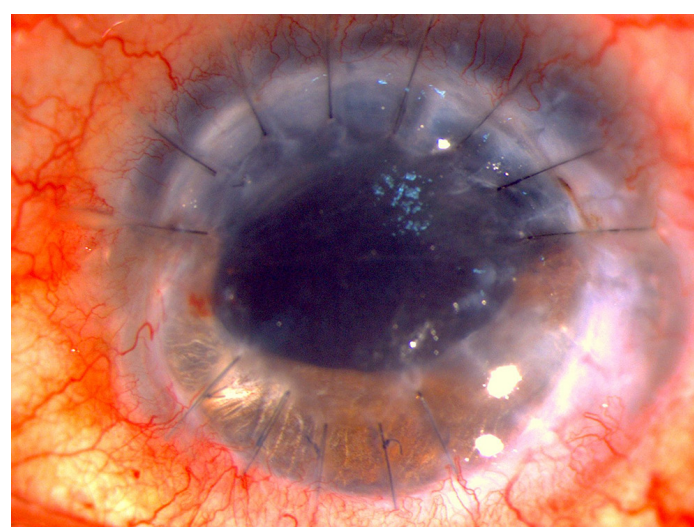

Figure 2 Postoperative day 1 showing well-apposed graft-host junction with minimal superior corneal oedema.

complications, and the best-corrected visual acuity is $20 / 80$ with a well-attached retina in presence of healthy optic disc and macula.

Wound dehiscence is one of the most dreaded complications following keratoplasty. GHJ healing occurs mainly at the level of endothelium and epithelium. Because of this, full thickness grafts are more prone for dehiscence as compared with lamellar grafts in which Descemet membrane and endothelium remain untouched giving extra support to transplanted cornea. The location for wound dehiscence is seen almost equal in all quadrants; in our case, the large dehiscence was located in the superior quadrant. ${ }^{2}$ Giant iridodialysis associated with wound dehiscence is rarely encountered in clinical practice. In this case, it was a large iridodialysis prolapsing out of the anterior chamber which was taken care of. The final outcome in these cases depends on many factors like time elapsed between injury

\section{Learning points}

- Keratoplasty is the common procedure performed, which carries the lifelong risk of graft-host junctionrelated complications like wound dehiscence.

- In cases of wound dehiscence being an ocular emergency, it should be tackled as early as possible with optimal surgical intervention for better long-term outcomes.

- In these cases, the factors which affect the visual outcome are extent of injury, time interval between the injury and treatment initiation, lens and retinal status. 


\section{Images in...}

and the intervention undertaken, Descemet membrane tear or detachment, tissue loss and importantly, the retinal status. Resuturing of the same graft to host bed is usually preferred rather than a new graft.

Contributors All authors have evaluated the case in detail and followed optimal surgical intervention for good visual outcome at the end of 5 months. They have also evaluated the critical educational value of the case and wrote the report.

Competing interests None declared.

Patient consent Obtained.
Provenance and peer review Not commissioned; externally peer reviewed.

(c) BMJ Publishing Group Ltd (unless otherwise stated in the text of the article) 2017. All rights reserved. No commercial use is permitted unless otherwise expressly granted.

\section{REFERENCES}

1 Foroutan A, Tabatabaei SA, Behrouz MJ, et al. Spontaneous wound dehiscence after penetrating keratoplasty. Int J Ophthalmol 2014;7:905-8

2 Renucci AM, Marangon FB, Culbertson WW. Wound dehiscence after penetrating keratoplasty: clinical characteristics of 51 cases treated at Bascom Palmer Eye Institute. Cornea 2006:25:524-9.

Copyright 2017 BMJ Publishing Group. All rights reserved. For permission to reuse any of this content visit http://group.bmj.com/group/rights-licensing/permissions.

BMJ Case Report Fellows may re-use this article for personal use and teaching without any further permission.

Become a Fellow of BMJ Case Reports today and you can:

- Submit as many cases as you like

- Enjoy fast sympathetic peer review and rapid publication of accepted articles

- Access all the published articles

Re-use any of the published material for personal use and teaching without further permission

For information on Institutional Fellowships contact consortiasales@bmjgroup.com

Visit casereports.bmj.com for more articles like this and to become a Fellow 